\title{
Development of Interactive Multimedia to Improve Letters Recognition for Children with Dyslexia
}

\author{
Arisul Mahdi ${ }^{*}$, Safaruddin ${ }^{2}$, Monica Rumapea ${ }^{3}$, and Johandri Taufan ${ }^{4}$ \\ ${ }^{1234}$ Universitas Negeri Padang \\ "Corresponding author. Email: arisulmahdi@fip.unp.ac.id
}

\begin{abstract}
This article discusses the development of interactive multimedia to improve the recognition of letters in dyslexic children. The background is the prevalence of dyslexic children who are quite a lot in elementary schools and the symptoms can even be found in children in early childhood education. This research uses the Research and Development (R \& D) method, with the following steps: Research and information collecting, Planning, Developing Preliminary form of product, Preliminary field testing, product revision operational field testing, product revision, dissemination. The results obtained are interactive multimedia applications to recognize letters that have been validated by experts and limited trials that show an increase in the enthusiasm of dyslexic children in learning to recognize letters and an increase in their ability to recognize letters.
\end{abstract}

Keywords: interactive multimedia, letter, dyslexia

\section{INTRODUCTION}

The era of globalization as evidenced by the increasing development of technology and the development of information today cannot be avoided. The world of education has also experienced the impact of these developments. Schools are required to be able to adapt technological developments to efforts to improve the quality of education in methods, learning tools, techniques, and media that can support the learning process.

Information systems by combining computer technology with telecommunications are called information technology [2] which can encourage changes and adjustments in the implementation of education. The industrial revolution 4.0 also shows technological developments that encourage automation in almost all aspects (in industry) so that it no longer requires human supervision. In addition, a new approach that connects the digital, physical, and biological world in principle and the existing reality, it seems that currently technology has changed the pattern of human interaction and the pattern of life that humans live [8]. Industry 4.0 is also a phase of the technological revolution that changes the way humans do activities in terms of scale, complexity, scope, and transformation from previous life experiences.

One of the areas that must be addressed in education along with the development of this technology is the field of learning for children with special needs, especially those who are considered digital native. For example, children have specific learning difficulties in reading or dyslexia. Through the use of information technology, it is hoped that learning can be improve to help overcome reading barriers experienced by children.

Learning disability or learning disability (LD) is familiarly said to be an obstacle that makes it difficult for the individual to carry out learning activities effectively. Learning difficulties are defined as barriers to learning in one basic academic field (such as arithmetic, reading and writing). Children with learning difficulties are grouped into three parts which include: Children with learning difficulties to count are called dyscalculia, children with writing difficulties are called dysgraphia and difficulties learning to read are also called dyslexia [3].

In the learning process, it is found that many children have difficulty reading (dyslexia). Types of reading and oral difficulties. It is characterized by difficulties in learning to read and write, remember letters, pronounce words and distinguish certain sounds from letters. Dyslexic children usually have poor shortterm memory, difficulties with orientation space, reading, spelling, writing and arithmetic [4].

The prevalence of reading difficulties at school age in the USA is a social concern. Based on the 2007 National Assessment of Educational Progress (NAEP) it was estimated that $34 \%$ of fourth grade children had reading difficulties (US Department of Education National Center for Education Statistics, 2007). Judging from the socioeconomic status (SES) and ethnic groups, $50 \%$ of children from low-income families have 
difficulty reading while those with low income are around $21 \%$. In addition, by ethnic group there were 54\% African-American descent, 51\% Hispanic descent and $23 \%$ American at baseline had reading difficulties [5]. This shows that reading difficulties are very important in everyday life, because by reading we can find out all the latest information and knowledge. In reading there are levels, one of which is reading the beginning. At the beginning of reading there is an emphasis on reading or the perceptual process, namely the introduction of the correspondence of a series of letters with language sounds. The series of letters such as vowels and consonants.

Reading is a knowledge that everyone must have without exception, including children with special needs, one of which is dyslexic children. Many learning methods have developed in several developed countries in Asia, this method is none other than a learning method by utilizing multimedia. Multimedia is known and deepened in the world of education, so education will be very prospective and very ready to face the challenges of modern times that have entered this postmodern era [6].

\section{METHOD}

This interactive multimedia development uses the research and development (R\&D) method. The steps taken are Research and information collecting as the basis for developing technology, Planning regarding the steps to be taken in product development, Developing Preliminary forms of products so that the products made are valid and reliable, Preliminary field testing for product trials, product revision operational field testing is used to make improvements after previous trials, product revision, and desimination.

\section{DISCUSSION}

1. Research and information collecting

Multimedia in learning is currently very large and has various types that can be used by children. However, not all children can like all existing learning multimedia. Based on the results of the observations that have been made, we are starting to look for solutions to overcome these problems. Several articles and books are our references in developing this interactive multimedia.

2. Planning

Based on the results of data collection that we have obtained, then we begin to compile the interactive multimedia forms and contents that will be created.

3. Developing preliminary form of product

We have developed multimedia according to the child's age and also the child's ability level according to their education level. For the initial design, we used informal writing so that it was unique and didn't make the child bored. Furthermore, we provide a menu of questions, voice menus, and exercise menus to give children understanding in learning to read.

4. Preliminary field testing

Before this multimedia was tested in the field, we asked for some input from the expert judgment regarding the multimedia we had made. They consist of media experts, specialists on children with special needs, and experts in reading material. Some of the suggestions given are regarding the sound on the exercise menu that doesn't exist so that the child still has difficulty understanding the material. In addition, there are still some menus that don't work on multimedia.

\section{Revision}

Based on the revisions we have received regarding interactive multimedia, we immediately fix the menus that are experiencing problems and provide a voice on the sample material provided.

6. Dissemination

After passing the revised results from the expert judgment, we conducted trials for the teacher to use the application. Based on the input from the teacher, the application is difficult to install on a laptop so that the teacher is confused. Thus, we made some repairs before this product could be used on parents, children and teachers.

\section{CONCLUSION}

This interactive multimedia is designed for children who have difficulty reading (dyslexia), especially children who do not recognize letters. This interactive multimedia uses Indonesian Language because it is very suitable to use in Indonesia education. In addition, this interactive multimedia can be used as a media for learning while playing.

\section{REFERENCES}

[1] J. L. Tjoe, "Peningkatan kemampuan membaca permulaan melalui pemanfaatan multimedia," J. Pendidik. Usia Dini, vol. 7, no. 1, pp. 17-48, 2013.

[2] Baharudin, "Keefektifan Media Belajar Berbasis Teknologi Informasi Dan Komunikasi," Tadrîs, vol. 5, no. 1, pp. 112127, 2010.

[3] M. Jamaris, Anak Berkesulitan Belajar Perseptif, Asesmen, dan Penanggunalangannya. Jakarta: Yayasan Penamas Murni, 2009.

[4] M. S. Abtahi, "Interactive multimedia learning object (IMLO) for dyslexic children," 
Procedia-Social Behav. Sci., vol. 47, pp. 12061210, 2012.

[5] M. B. Morris, R. D., Lovett, M. W., Wolf, M., Sevcik, R. A., Steinbach, K. A., Frijters, J. C., \& Shapiro, "Multiple- Component Remediation for Developmental Reading Disabilities: IQ, Socioeconomic Status, and Race as Factors in Remedial Outcome," J. Learn. Disabil., vol. 45, no. 2, pp. 99-127, 2012.

[6] Niken dan haryanti Ariani, pembelajaran multimedia di sekolah: pedoman pembelajaran inspiratif, konstruktif, dan prospektif. 2010.

[7] N. H. Ekhsan, H. M., Ahmad, S. Z., Halim, S. A., Hamid, J. N., \& Mansor, "The Implementation of Interactive Multimedia in Early Screening of Dyslexia," Int. Conf. Innov. Manag. Technol. Res., pp. 566-569, 2012.

[8] M. Abdurahman, Pendidikan Bagi Anak Kesulitan Belajar. Jakarta: Rineka Cipta, 2012.

[9] S. M. Daud and H. Abas, ",Dyslexia baca" mobile app - The learning ecosystem for dyslexic children," Proc. - 2013 Int. Conf. Adv. Comput. Sci. Appl. Technol. ACSAT 2013, pp. 412-416, 2013, doi: 10.1109/ACSAT.2013.87.

[10] Tjandrawinata, "industri 4.0 revolusi industry abad ini dan pengaruhnya pada bidang kesehatan dan bioteknologi," medicinus, vol. 29, no. 1, 2016.

[11] R. Skiada, E. Soroniati, A. Gardeli, and D. Zissis, "EasyLexia: A mobile application for children with learning difficulties," Procedia Comput. Sci., vol. 27, no. Dsai 2013, pp. 218228, 2014, doi: 10.1016/j.procs.2014.02.025.

[12] P.J. Madeira, C. Silva, L. Marcelino, and Ferreira, "Assistive Mobile Applications for Dyslexia," ProcediaComput. Sci., vol.64, pp. 417-424, 2015, doi: 10. 1016/j.procs.2015.08.535

[13] V. Subramaniam, "Disleksia dalam konteks pembelajaran bahasa di Malaysia," Pertanika J. Soc. Sci. Hum, vol. 16, no. 2, pp. 115-139., 2008.

[14] Sugiyono, Metode Penelitian. Bandung: Alfabeta, 2016.

[15] B. W. R. dan Gall, Educational Research: An Introduction. 1983. 


\section{APPENDIX 1}

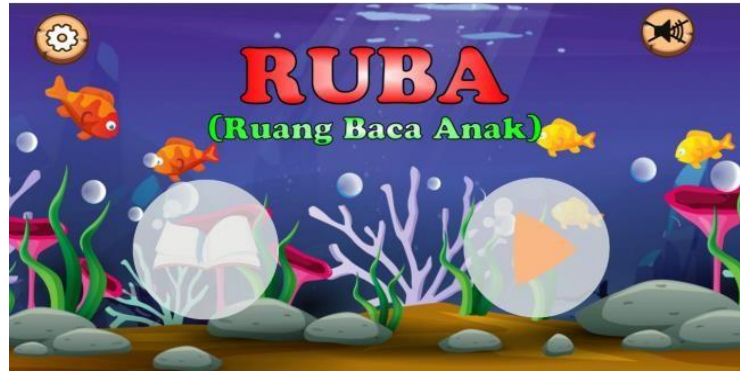

Picture 1: Main menu for study

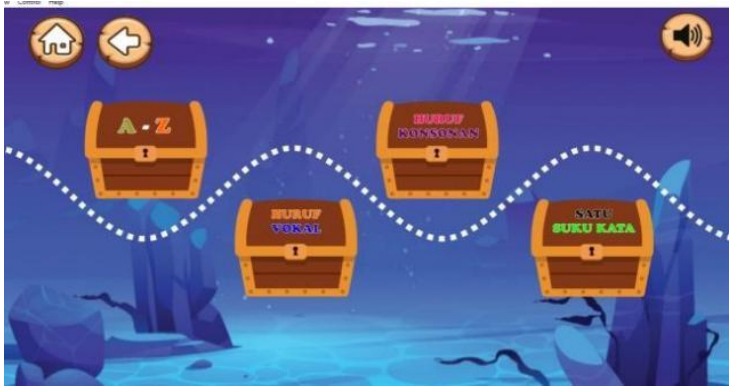

Picture 2: Menu for recognizing letters

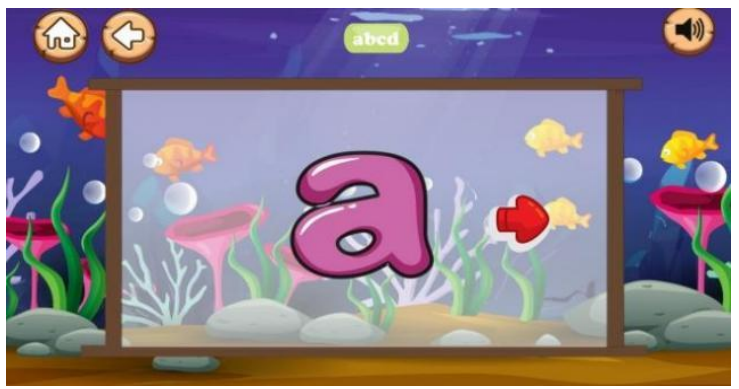

Picture 3: Menu for recognizing vowel

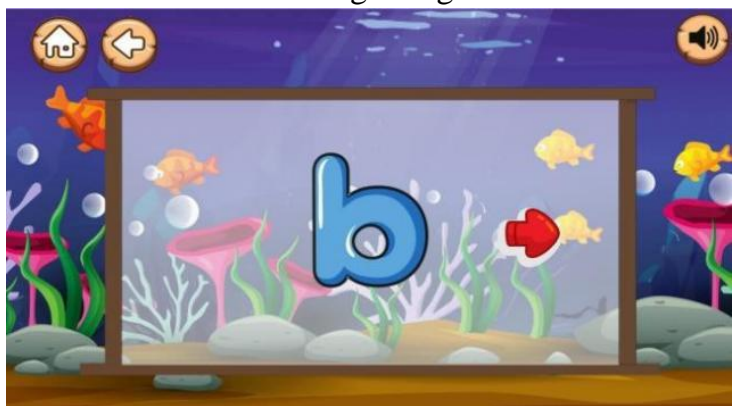

Picture 4: Menu for recognizing consonant

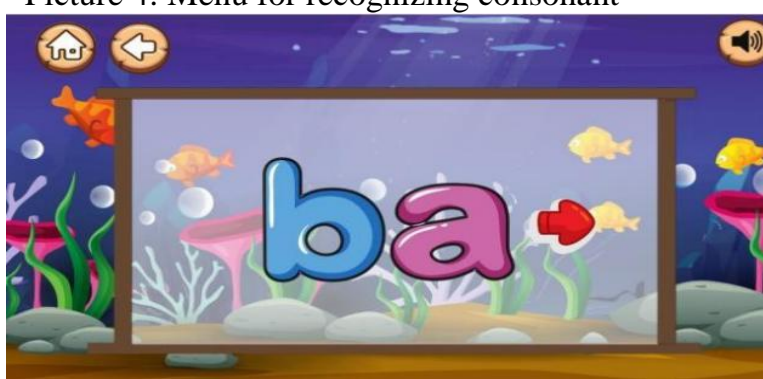

Picture 5: Menu to recognize an open syllable

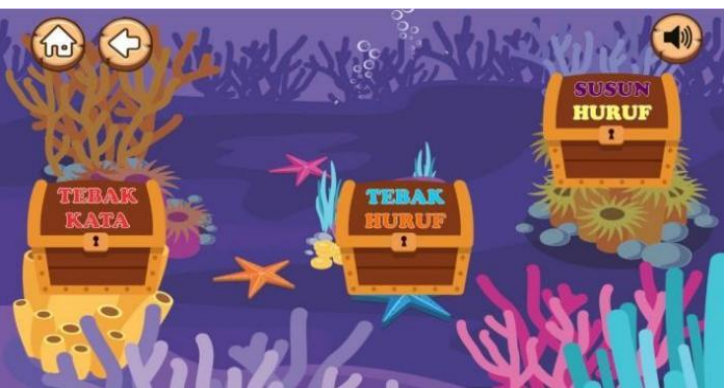

Picture 6: Main menu for games

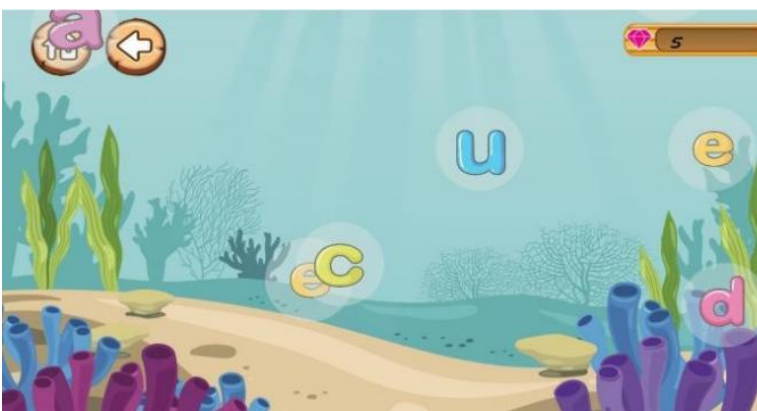

Picture 7: Menu for guess the letters game

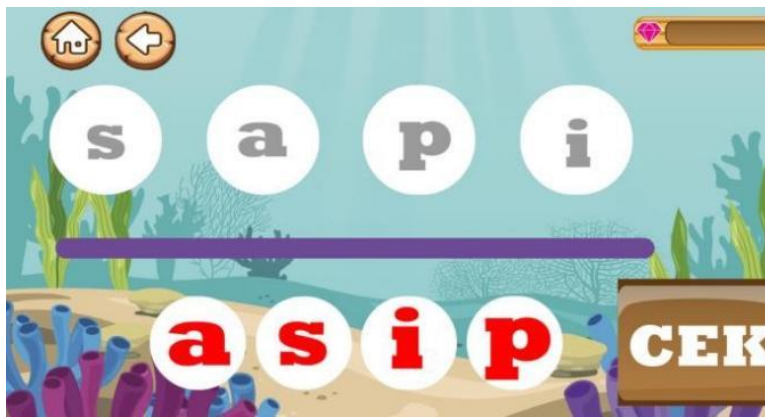

Picture 8: Menu for letters pairs game

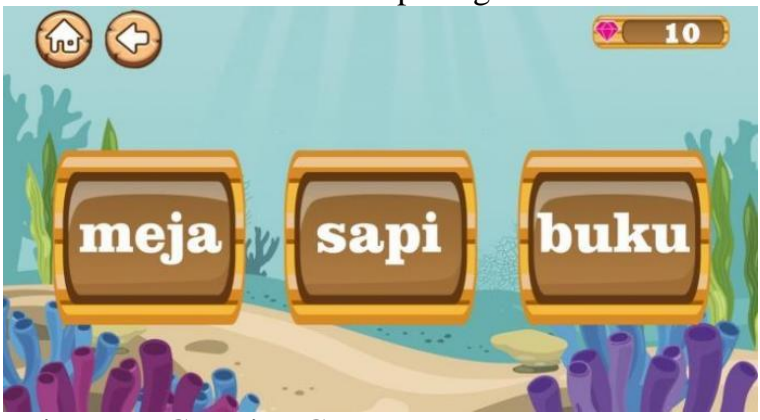

Picture 9: Guessing Game 